\title{
Karakteristik Pasien yang Menjalani Pemeriksaan Brainstem Evoked Response Audiometry (BERA) di RSUP Dr. Kariadi Semarang
}

\author{
Rano Aditomo ${ }^{1 *}$, Dian Ayu Ruspita ${ }^{2}$ \\ ${ }^{1}$ Bagian KSM IKTHT-KL FK UNISSULA; RS ISLAM SULTAN AGUNG Semarang \\ ${ }^{2}$ Bagian KSM IKTHT-KL FK UNDIP; RSUP Dr. Kariadi Semarang
}

\begin{abstract}
ABSTRAK
Brainstem Evoked Response Audiometry (BERA) adalah suatu pemeriksaan elektrofisiologi auditorik untuk menilai integritas dari sistem pendengaran sentral dan perifer secara obyektif dan tidak invasif. Pemeriksaan BERA diusulkan dilakukan pada setiap bayi baru lahir sebagai pemeriksaan standar yang dilakukan untuk identifikasi awal gangguan pendengaran pada bayi baru lahir. Angka kejadian tuli kongenital antara 4-6/1000 kelahiran hidup di negara berkembang. Penelitian ini bertujuan untuk mengetahui karakteristik pasien yang menjalani pemeriksaan BERA meliputi usia, jenis kelamin, nilai ambang pendengaran, faktor risiko dan penyebaran kejadian di wilayah Jawa Tengah. Penelitian ini bersifat deskriptif retrospektif menggunakan catatan medis pasien yang menjalani pemeriksaan BERA yang dilakukan di RS. Dr. Kariadi Semarang periode Januari 2016 - Desember 2016. Hasil terdapat 515 pasien yang menjalani pemeriksaan BERA dari 35 Kabupaten dan Kota yang ada di Jawa Tengah. Pasien yang paling banyak menjalani pemeriksaan BERA berasal dari kota Semarang. Paling banyak pasien menjalani pemeriksaan BERA usia 0-3 tahun, dengan faktor risiko paling sering adalah kejang demam dan hasil profound adalah yang terbanyak. Kesimpulan yang dapat diambil adalah kejadian kurang dengar pada anak 0-3 tahun dengan nilai ambang dengar lebih dari 86 dB banyak terjadi di Kota Semarang. Pemeriksaan BERA belum dapat menjangkau daerah lain di sekitar Jawa Tengah.
\end{abstract}

Kata kunci: Brainstem Evoked Response Audiometry; pemeriksaan elektrofisiologi auditorik; tuli kongenital

\begin{abstract}
Introduction: Brainstem Evoked Response Audiometry (BERA) is an auditory electrophysiological examination to objectively and non-invasively assess the integrity of the central auditory system. BERA examination is proposed to be carried out on every newborn as a standard examination to identify early hearing loss in newborns. The incidence of congenital deafness between 4-6 babies in 1000 live births in developing countries. Purpose: This study aimed to determine the characteristics of patients undergoing BERA examination including age, gender, hearing threshold values, risk factors, and the spread of events in the Central Java region. Methods: This was a retrospective descriptive study utilizing medical records of patients undergoing BERA examination conducted at the hospital. Dr. Kariadi Semarang from January 2016 - December 2016. There were 515 patients who underwent BERA examination from 35 districts and cities in Central Java. Most patients undergoing BERA examination came from the city of Semarang. Results: Most patients underwent BERA examination aged 0-3 years, with the most frequent risk factors being febrile seizures and profound was found to be the highest results. Discussion: The incidence of hearing loss in children 0-3 years with a hearing threshold of more than $86 \mathrm{~dB}$ was the highest incidence in Semarang within 2016. Conclusion: BERA examination has not been able to reach other areas around Central Java.
\end{abstract}

Keywords: Brainstem Evoked Response Audiometry; auditory electrophysiological examination; congenital deafness

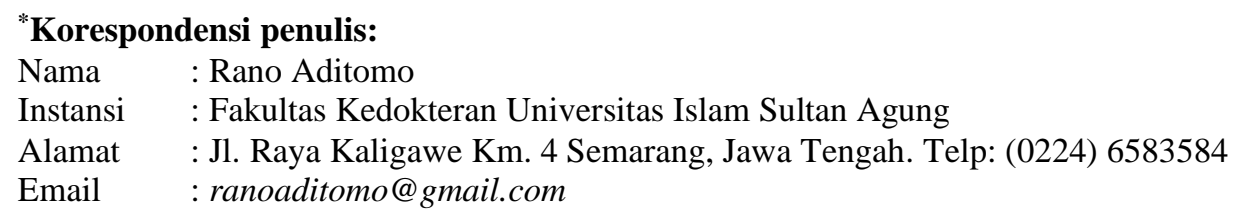




\section{Pendahuluan}

Brainstem Evoked Response Audiometry (BERA) adalah suatu pemeriksaan elektrofisiologi auditorik untuk menilai integritas dari sistem pendengaran secara obyektif dan tidak invasif. Istilah lain BERA adalah Auditory Brainstem Response (ABR), Evoked Response Audiometry (ERA). Joint Committee on Infant Hearing (JCIH) pada tahun 2019, telah mengusulkannya pemeriksaan BERA pada setiap bayi baru lahir sebagai pemeriksaan standar yang dilakukan untuk identifikasi awal gangguan pendengaran pada bayi baru lahir. Studi sebelumnya menjelaskan bahwa pemeriksaan BERA adalah asesmen penilaian pendengaran yang objektif. Keuntungan utama dari prosedur BERA ini adalah kemampuannya untuk skrining lebih lanjut dimana prosedur konvensional audiometri lainnya mungkin tidak memperoleh hasil yang memuaskan. Pemeriksaan BERA ini juga dapat digunakan sebagai tes skrining untuk kondisi tuli pada bayi yang berisiko tinggi. Diagnosis yang akurat dan penanganan rehabilitasi dini akan mengurangi kecacatan pada anak-anak. ${ }^{1-3}$

Angka kejadian tuli kongenital antara 46/1000 kelahiran hidup di negara berkembang, sedangkan di Amerika antara 1-3/1000 kelahiran. Hasil studi World Health Organization (WHO) dalam WHO multi centre study tahun 1998, Indonesia termasuk urutan ke 4 (empat) negara di Asia Tenggara dengan prevalensi ketulian yang cukup tinggi $(4,6 \%), 3$ (tiga) negara lainnya adalah Sri Lanka (8,8\%), Myanmar $(8,4 \%)$, dan India $(6,3 \%) .{ }^{4,5} \mathrm{Hal}$ ini menunjukkan pentingnya kejadian tuli kongenital ini agar segera diberikan penanganan yang lebih tepat dan akurat dengan melakukan pengkajian pada berbagai faktor yang mempengaruhi terjadinya kejadian tuli terutama di Indonesia.

Penelitian sebelumnya menjelaskan tentang tingginya insiden gangguan pendengaran pada bayi berisiko tinggi dengan latar belakang sosial ekonomi, kekurangan gizi, hygiene yang buruk, fasilitas medis yang kurang memadai, tingkat pengetahuan, dan berbagai faktor lainnya. Kurang adekuatnya fasilitas medis yang tersedia juga menyebabkan perawatan antenatal yang buruk yang dapat meningkatkan kejadian asfiksia dan gangguan pendengaran. ${ }^{6}$ Kejadian gangguan pendengaran lebih tinggi di negara berkembang karena perawatan antenatal dan neonatal yang buruk. ${ }^{7}$ Bayi mengalami kondisi asfiksia saat lahir, berat badan lahir rendah (BBLR) atau prematur, terpapar obat ototoxik, sepsis atau meningitis, hiperbilirubinemia berat, otitis dan sindrom Down juga merupakan faktor risiko lainnya yang menyebabkan ketulian. ${ }^{8}$

Hal ini menunjukkan pentingnya deteksi dini atau evaluasi adanya gangguan pendengaran sensorineural (SNHL) dan/atau konduktif (CHL) pada bayi baru lahir dan bayi (termasuk gangguan pendengaran onset yang tertunda) dan setelah anak diidentifikasi berisiko mengalami gangguan pendengaran. Dengan dilakukannya prosedur BERA, deteksi dan evaluasi adanya gangguan pendengaran menjadi lebih mudah terutama pada pasien anak-anak. ${ }^{6}$ Mengingat tingginya angka kejadian tuli kongenital sementara hingga saat ini belum ada data mengenai gambaran pasien yang menjalani pemeriksaan BERA di RS. Dr. Kariadi Semarang, maka penulis tertarik untuk melakukan penelitian mengenai gambaran demografi pasien yang menjalani pemeriksaan BERA di RS. Dr. Kariadi periode Januari 2016 hingga Desember 2016. Dengan adanya data dari hasil penelitian ini diharapkan diketahui masalah pendengaran yang memiliki kejadian paling tinggi dan faktor risiko yang paling banyak terjadi sehingga dapat perhatian bagi petugas Kesehatan dan masyarakat.

\section{Metode}

Penelitian ini bersifat deskriptif retrospektif menggunakan catatan medis pasien yang menjalani pemeriksaan BERA yang dilakukan di RS. Dr. Kariadi Semarang. Sampel penelitian adalah seluruh pasien yang menjalani pemeriksaan BERA di RS. Dr. Kariadi Semarang dalam kurun waktu Januari 2016 hingga Desember 2016. Kriteria eksklusi pada penelitian ini adalah penderita dengan catatan medis yang tidak lengkap. Data selanjutnya ditabulasi dan dipaparkan secara deskriptif. 


\section{Hasil dan Pembahasan}

Dari data catatan medis yang telah dikumpulkan, pasien yang menjalani pemeriksaan BERA di RS. Dr. Kariadi periode Januari 2016 - Desember 2016 sebanyak 529 pasien. Data penelitian yang tidak diikutsertakan sebanyak 14 pasien, karena catatan medis tidak lengkap. Hasil penelitian ini menunjukkan karakteristik data penelitian berdasarkan usia dan jenis kelamin (Tabel 1), karakteristik data penelitian berdasarkan sebaran wilayah (Tabel 2), karakteristik data penelitian berdasarkan faktor risiko (Tabel 3), karakteristik data penelitian berdasarkan ambang dengar/derajat kurang dengar (Tabel 4) dan distribusi faktor risiko (Gambar 1).

Tabel 1. Karakteristik data penelitian berdasarkan usia dan jenis kelamin

\begin{tabular}{lcc}
\hline Kategori & Jumlah & $\begin{array}{c}\text { Persentase } \\
(\%)\end{array}$ \\
\hline Usia & & \\
0-3 tahun & 302 & 58,64 \\
3-6 tahun & 158 & 30,68 \\
> 6 tahun & 55 & 10,68 \\
Jenis Kelamin & & \\
$\quad$ Laki - Laki & 306 & 59,41 \\
Perempuan & 209 & 40,59 \\
\hline
\end{tabular}

Tabel 1 menjelaskan tentang karakteristik pasien berdasarkan usia dan jenis kelamin. Selama periode tersebut didapatkan pasien laki-laki lebih banyak dari pada wanita dengan jumlah $306(59,41 \%)$ banding 209 (40,59\%), yang ditunjukkan pada tabel 1. Dari catatan medis, karakteristik data penelitian berdasarkan usia, urutan terbanyak adalah rentang usia 0-3 tahun, yaitu sebanyak 302 orang $(58,64 \%)$, diikuti usia 3-6 tahun sebanyak 158 orang $(30,68 \%)$, dan terakhir usia $>6$ tahun sebanyak 55 orang $(10,68 \%)$.

Sedangkan pada Tabel 2, karakteristik dari sebaran wilayah paling banyak berasal dari kota Semarang sebanyak 130 pasien. Kemudian diikuti Kabupaten \& Kota Pekalongan sebanyak 39 pasien dan Kabupaten Kudus pada urutan ketiga yaitu sebanyak 36 pasien. Pada penelitian ini ditemukan sebanyak 164 pasien $(31,84 \%)$ dan faktor risiko tunggal yaitu sebanyak 158 pasien $(30,68 \%)$.

Tabel 2. Karakteristik Data Penelitian Berdasarkan Sebaran Wilayah

\begin{tabular}{lcc}
\multicolumn{3}{c}{ Berdasarkan Sebaran Wilayah } \\
\hline Wilayah & Jumlah & \% \\
\hline Kab. Banjarnegara & 1 & 0,19 \\
Kab. Banyumas & 3 & 0,58 \\
Kab. Batang & 15 & 2,91 \\
Kab. Blora & 8 & 1,55 \\
Kab. Boyolali & 3 & 0,58 \\
Kab. Brebes & 13 & 2,52 \\
Kab. Cilacap & 2 & 0,38 \\
Kab. Demak & 31 & 6,01 \\
Kab. Grobogan & 20 & 3,88 \\
Kab. Jepara & 32 & 6,21 \\
Kab. Karanganyar & 0 & 0 \\
Kab. Kebumen & 0 & 0 \\
Kab. Kendal & 33 & 6,40 \\
Kab. Klaten & 3 & 0,58 \\
Kab. Kudus & 36 & 7 \\
Kab. Magelang & 0 & 0 \\
Kab. Pati & 27 & 5,24 \\
Kab. \& Kota & 39 & 7,57 \\
Pekalongan & & \\
Kab. Pemalang & 15 & 2,91 \\
Kab. Purbalingga & 3 & 0,58 \\
Kab. Purworejo & 0 & 0 \\
Kab. Rembang & 9 & 1,74 \\
Kab. Semarang & 34 & 6,60 \\
Kab. Sragen & 0 & 0 \\
Kab. Sukoharjo & 0 & 0 \\
Kab. Tegal & 12 & 6,01 \\
Kab. Temanggung & 0 & 2,33 \\
Kab. Wonogiri & 0 \\
Kab. Wonosobo & 1 & 0,19 \\
Kota Magelang & 0,38 \\
Kota Salatiga & 2,33 \\
Kota Semarang & 25,24 \\
Kota Surakarta & & \\
\hline
\end{tabular}

Tabel 3. Karakteristik data penelitian berdasarkan faktor risiko

\begin{tabular}{lcc}
\hline Faktor Risiko & Total & $\begin{array}{c}\text { Persentasi } \\
\mathbf{( \% )}\end{array}$ \\
\hline Multipel & 164 & 31,84 \\
Tunggal & 158 & 30,68 \\
Tidak ada & 175 & 33,98 \\
\hline
\end{tabular}

Pada tabel 3 menunjukkan karakteristik data penelitian berdasarkan faktor risiko yang menyebabkan pasien menderita kurang dengar yang dibagi menjadi 3 kategori yaitu multiple, single, dan tidak ada faktor risiko. Dari catatan medis yang didapat pasien menjalani pemeriksaan BERA karena penyakit komorbid 
lainnya, yang terbanyak adalah global developmental delayed dimana pasien juga akan mengalami keterlambatan bicara, sehingga tidak adanya faktor risiko menempati urutan pertama yaitu sebanyak 175 pasien $(33,98 \%)$. Faktor risiko lebih dari satu (multiple) didapatkan

Tabel 4. Karakteristik data penelitian berdasarkan ambang dengar / derajat kurang dengar

\begin{tabular}{lcc}
\hline $\begin{array}{c}\text { Ambang dengar / derajat } \\
\text { (WHO) }\end{array}$ & Total & $\begin{array}{c}\text { Persentase } \\
(\%)\end{array}$ \\
\hline $20 \mathrm{~dB}$ (normal) & 206 & 40 \\
$\geq 20 \mathrm{~dB}-40 \mathrm{~dB}$ (ringan) & 29 & 5,63 \\
$\geq 41 \mathrm{~dB}-60 \mathrm{~dB}$ (sedang) & 36 & 7,0 \\
$\geq 61 \mathrm{~dB}-85 \mathrm{~dB}$ (berat) & 17 & 3,30 \\
$\geq 86 \mathrm{~dB}$ (sangat berat) & 227 & 44,07 \\
\hline
\end{tabular}

Karakteristik berikutnya adalah berdasarkan ambang dengar/derajat kurang pendengaran. Dari catatan medis yang ada kurang pendengaran derajat sangat berat / profound merupakan hasil pemeriksaan BERA yang paling banyak, yaitu 227 pasien (44,07\%). Hasil pemeriksaan BERA tersering berikutnya adalah pendengaran normal, yaitu sebanyak 206 pasien (40\%). Berturut-turut menempati hasil yang paling sedikit adalah kurang pendengaran derajat sedang, derajat ringan kemudian paling sedikit derajat berat, yaitu 36 pasien $(7,0 \%), 29$ pasien $(5,63 \%)$, dan 17 pasien $(3,3 \%)$ (tabel 4$)$.

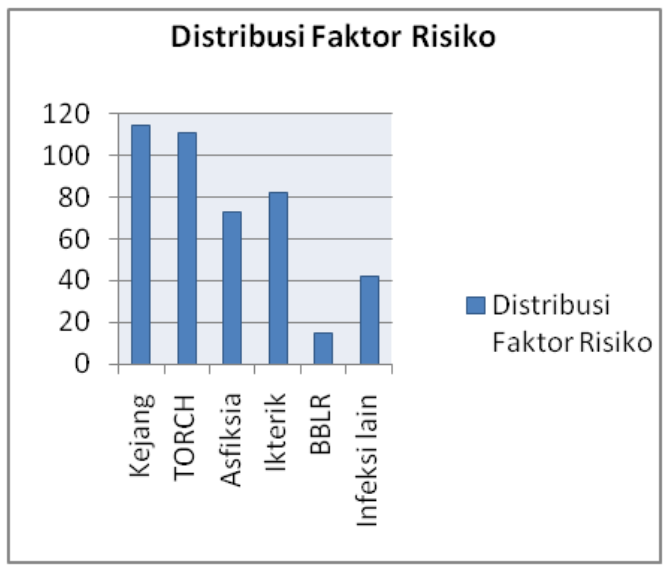

Gambar 1. Distribusi faktor risiko

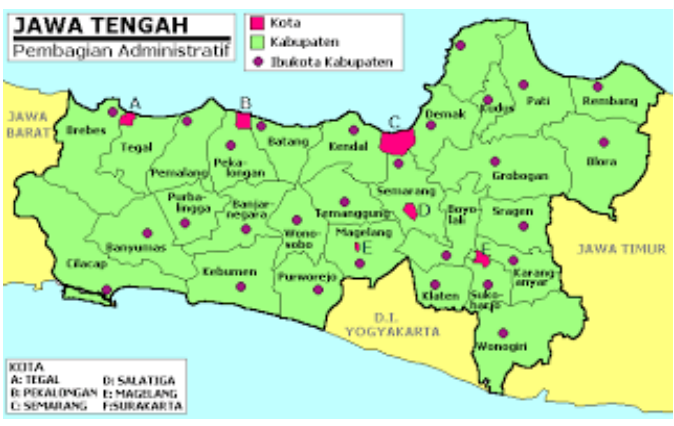

Gambar 1. Peta wilayah Jawa Tengah

Dari data penelitian faktor risiko dikelompokkan menjadi 6 kelompok besar. Kelompok dengan risiko kejang, infeksi Toxoplasmosis and Other (Syphilis, Varicellazoster, Parvovirus B19), Rubella, Cytomegalovirus, Herpes Simplex Virus/ TORCH, asfiksia, ikterik, Berat Bayi Lahir Rendah (BBLR), dan infeksi lain. Kelompok kejang memiliki angka terbanyak yaitu 114 pasien, dimanaa kejang meliputi kejang demam maupun kejang tanpa demam. Kelompok faktor risiko tertinggi yang kedua adalah infeksi TORCH sebanyak 111 pasien. Infeksi ini didapatkan dari data catatan medis baik anamnesis maupun hasil laboratorium seperti: riwayat cacar, campak, bintik/bercak merah, hasil laboratorium Rubella (+), CMV (+), Toxoplasmosis $(+)$, maupun pasien dengan Cytomegalovirus \& Rubella Syndrome (CRS). Menduduki peringkat ketiga adalah faktor risiko ikterik, yakni 82 pasien (lihat grafik 1). Pada kelompok ini pengertian ikterik adalah diketahui dari anamnesis orangtua / keluarga tentang riwayat sakit kuning saat bayi (ikterik neonatus) dan dari hasil laboratorium yang menunjukkan hiperbilirubinemia. Sedangkan kelompok BBLR adalah semua pasien dengan berat bayi lahir < 2500 gram, faktor risiko tersebut didapatkan sebanyak 15 pasien. Pada distribusi faktor risiko pada kelompok infeksi lain didapatkan sebanyak 42 pasien, meliputi Otitis Media Akut (OMA), Otitis Media Efusi (OME), Otitis Media Kronik (OMK), infeksi Tuberculosis, bronkitis, parotitis, flu Singapore, diare, demam berdarah, dan meningitis. 
Penelitian ini menunjukkan kejadian kurang dengar lebih banyak pada laki-laki daripada perempuan. Hal ini sesuai dengan penelitian sebelumnya yang dilakukan Wijana (2014) laki-laki dibandingkan perempuan yaitu 1,53:1 dari 702 pasien. ${ }^{9}$ Keadaan tersebut kemungkinan terjadi oleh karena perbedaan anatomi pada jaras pendengaran perifer, volume liang telinga pada laki-laki relatif lebih luas apabila dibandingkan dengan perempuan, di samping itu koklea pada perempuan lebih pendek bila dibandingkan koklea laki-laki. Hal tersebut dapat menyebabkan stimulus pada perempuan lebih cepat sampai, juga menyebabkan kekakuan pada membran basilaris. ${ }^{9}$ Pasien lebih banyak berasal dari kota Semarang, dikarenakan dekatnya fasilitas kesehatan dan tersedianya fasilitas yang memadai untuk dilakukannya skrining pendengaran atau pemeriksaan BERA berada di kota yang sama. Pasien yang berasal dari wilayah lain di Jawa Tengah yang tidak memeriksakan diri di kota Semarang, dikarenakan telah dirujuk ke kota lain yang tersedia pemeriksaan BERA dan jaraknya lebih dekat (gambar 1).

Data WHO menyebutkan bayi lahir tuli 0,1-0,2\%, sehingga kurang lebih ada 5200 bayi tuli di Indonesia per tahun yang berisiko gangguan perkembangan bahasa dan komunikasi, berdampak turunnya kemampuan akademik dan kualitas SDM dan akan menjadi warga terbelakang, tidak mandiri dan tidak sejahtera. ${ }^{5,10}$ Sedangkan dari penelitian ini menunjukkan hanya 515 pasien dari 39.298 .765 atau sekitar $0,0013 \%$ pasien yang menjalani pemeriksaan BERA. Hal ini menunjukkan bahwa pemeriksaan BERA belum dapat menjangkau daerah lain di sekitar Jawa Tengah. Untuk itu melalui komite daerah PGPKT (Penanggulangan Gangguan Pendengaran dan Ketulian) yang memiliki program "Pendengaran Sehat 2030" harus lebih giat dalam menjaring pasien dengan faktor risiko kurang pendengaran di berbagai wilayah di Jawa Tengah.

Neonatus yang memiliki faktor risiko tinggi harus dilakukan skrining gangguan pendengaran pada usia satu bulan untuk selanjutnya dilakukan intervensi pada usia 6 bulan. Pada penelitian terdahulu didapatkan bahwa bayi prematur dengan komorbiditas hipokalsemia, hipoglikemia, apnea, penggunaan oksigen dalam waktu lama memiliki kelainan pendengaran yang signifikan pada skrining awal dibandingkan dengan mereka yang tidak memiliki penyakit penyerta. Tujuan pemeriksaan gangguan pendengaran adalah untuk mengidentifikasi gangguan pendengaran sejak dini sehingga intervensi segera dapat dilakukan untuk mengurangi morbiditas yang terkait dengan gangguan pendengaran. ${ }^{11}$

Rentang usia pada penelitian ini yang paling banyak melakukan pemeriksaan BERA adalah usia 0-3 tahun, dimana periode emas anak dilakukan habilitasi adalah kurang dari 3 tahun. Tiga tahun pertama kehidupan anak adalah masa perkembangan dan pematangan otak, saat ini juga merupakan periode perkembangan bicara dan bahasa yang intensif. ${ }^{9}$ Diagnosis lebih awal, pada literatur memungkinkan keberhasilan intervensi terapi wicara pada anak dengan gangguan pendengaran. ${ }^{12}$ Hal ini menunjukkan bahwa kewaspadaan orang tua maupun tenaga medis terhadap anak yang terlambat bicara sangat tinggi.

Beberapa faktor risiko yang perlu dipertimbangkan dan telah ditetapkan oleh JCIH tahun 2019, antara lain kelainan yang berhubungan dengan sindroma tertentu yang diketahui mempunyai hubungan dengan gangguan SNHL atau CHL, riwayat keluarga dengan gangguan pendengaran, perawatan NICU selama 48 jam atau lebih, anomali kraniofasial, infeksi intaruterin $\mathrm{TORCH}$, anemia defisiensi besi, bayi lahir prematur, otitis media berulang atau dengan efusi dan lainnya., ${ }^{2,13-15}$ Berdasarkan hal itu, penelitian ini mengklasifikasikan menjadi 6 kelompok, yaitu kelompok dengan faktor risiko kejang, infeksi TORCH, asfiksia, BBLR dan infeksi lainnya. Penelitian ini menunjukkan faktor risiko yang paling banyak adalah kejang, dimana penelitian yang ada kejang demam berulang berkaitan dengan keterlambatan bicara pada anak usia 2,5 tahun secara signifikan. Prevalensi keterlambatan bicara yang disertai 
adanya gangguan pendengaran yaitu sebanyak $88,3 \%$, sehingga prosedur BERA juga memerlukan pemeriksaan penunjang lainnya seperti Oto Accoustic Emission (OAE) untuk menegakkan keakuratan diagnosa gangguan pendengaran. ${ }^{9,16}$

\section{Kesimpulan}

Kejadian kurang dengar pada anak 0-3 tahun dengan nilai ambang dengar lebih dari 86 dB banyak terjadi di Kota Semarang. Pemeriksaan BERA belum dapat menjangkau daerah lain di sekitar Jawa Tengah dikarenakan jauhnya fasilitas kesehatan dan kurangnya fasilitas kesehatan dalam mendeteksi secara dini adanya gangguan pendengaran.

\section{Ucapan Terima Kasih}

Para peneliti mengucapkan terima kasih pada bagian KSM IKTHT-KL FK UNISSULA; RS ISLAM SULTAN AGUNG Semarang atas dukungannya selama penulisan artikel ini.

\section{Referensi}

1. Purdy S, Kelly A. Auditory evoked response testing in infants and children, In: Madell J, Flexer C editors. Pediatric Audiology, Diagnosis, Technology, and Management. Second ed. New York: Thieme Medical Publishers; 2014.

2. Joint Committee on Infant Hearing. Year 2019 Position Statement: Principles and Guidelines for Early Hearing Detection and Intervention Programs. Journal of Early Hearing Detection and Intervention. 2019;4(2):1-44.

3. Thiagarajan B. Brain stem evoked response audiometry A Review. Otolaryngology online journal. 2015;5:1-7.

4. Kusumagani H, Purnami N. Newborns hearing screening with otoacoustic emissions and auditory brainstem response. $\mathrm{J}$ Community Med Pub Health Res. 2020;1(1):1-13.

5. Direktorat Jenderal Bina Kesehatan Masyarakat. Keputusan Menteri Kesehatan Republik Indonesia Nomor

\section{9/MENKES/SK/XI/2006:}

Rencana

strategi nasional penangulangan gangguan pendengaran dan ketulian untuk mencapai sound hearing 2030. Jakarta: Direktorat Jenderal Bina Kesehatan Masyarakat; 2010.

6. Mukherjee SS, Mukherjee S, Sarkar KD. Prevalence of Hearing Loss in High Risk Infants of Mediocre Socio-economic Background at Around One Year of Age and Their Correlation with Risk Factors. Indian J Otolaryngol Head Neck Surg. 2013;65(Suppl 3):598-603.

7. Mishra UK, Kalita J. Clinical neurophysiology: nerve conduction, electromyography, evoked potentials. 2nd edn. New Delhi: Reed Elsevier India Private Ltd; 2006.

8. Homes GL, Jones HR Jr., Moshe SL. Clinical neurophysiology of infancy, childhood and adolescence. Butterworth Heinemann: Elsevier; 2006.

9. Wijana, Syamsuddin A, Dewi YA. Gelombang Auditory Brainstem Respone (ABR) pada Anak Dibawah Lima Tahun. 2014;46 (3):183-8.

10. Husni TH, Thursina T. Pola Gangguan Pendengaran Di Poliklinik Telinga Hidung Tenggorok Kepala Leher (THT-KL) Rsud Dr. Zainoel Abidin Banda Aceh Berdasarkan Audiometri. Jurnal Kedokteran Syiah Kuala. 2012;12(1):16-22.

11. Mandal S, Banerjee M, Ghosh P, Mallick AK, Kanjilal S. Early Detection of Hearing Impairment In High Risk New-Borns. Pediatric Oncall Journal. 2019;16(4):111114.

12. Banerjee S, Gorai S, Chattaraj W. A Comparative Study on Brain Stem Evoked Response Audiometry among Pre-school Children with Normal and Delayed Development of Speech Attending Bankura Sammilani Medical College. International Journal of Contemporary Medical Research. 2020;7(1):A9-A12.

13. Annemarie MV, Vincent WVJ, Akhgar G, Jacqueline JS, Frank CV, Albert H, Henning $\mathrm{T}$, et al. Febrile seizures and behavioural and 
cognitive outcomes in preschool children: the Generation R Study. Developmental Medicine \& Child Neurology. 2012;54:1006-1011.

14. Sundagumaran H, Seethapathy J. Auditory brainstem response in infants with iron deficiency anemia. Int $\mathrm{J}$ Pediatr Otorhinolaryngol. 2019;117:78-81.

15. Seethapathy J, Boominathan P, Uppunda AK, Ninan B. Auditory brainstem response in very preterm, moderately preterm and late preterm infants. Int $\mathrm{J}$ Pediatr Otorhinolaryngol. 2018;111:119-127.

16. Sari SNL, Memy YD, Ghanie A. Angka Kejadian Delayed Speech Disertai Gangguan Pendengaran pada Anak yang Menjalani Pemeriksaan Pendengaran di Bagian Neurootologi IKTHT-KL RSUP Dr.Moh. Hoesin. Jurnal Kedokteran Dan Kesehatan. 2015;2(1):121-127. 